\title{
光ファイバの製造方法
}

\author{
田中豪太郎*，松井 和則*
}

\section{A Review of Optical Fiber Fabrication}

\section{1. まえがき}

光ファイバは，過去10年間における製造技術開発の画 期的な進展により, 現在長距離大容量の公衆通信用基幹 線路への適用を始めとし，コンピュータ，データリンク 等産業用情報処理システム, 七ンサ等への応用が始まっ ている。本稿では，これら光ファイバ製造技術の現状を 紹介する。

\section{2. 光ファイバおよびその構成材料}

光ファイバの基本構成として，その代表的な断面構造 例を図 1 に示す。コアは光が伝搬する部分であり, 光を 集中させるために, その屈折率が周辺のクラッドよりも 高くなっている。第 1 被覆および緩衝層は, シリコン樹 脂などの軟い樹脂となっており，外部圧力，微小曲りな どから光伝送特性を保護している。第 2 被覆はナイロン などの硬い樹脂となっており，ファイバを機械的に保護 する。

光ファイバに要求される基本的な特性は，(1)光伀送損 失の少ないこと，(2)光伝送歪の少ないこと，(3)強度・耐 候性に優れることであり, かつこれら特性の安定性・信 頼性の高いことが重要である。

(1)については, その損失要因を表 1 にまとめる。構成 材料に固有なものが, 電子遷移に基づく紫外吸収, 格子

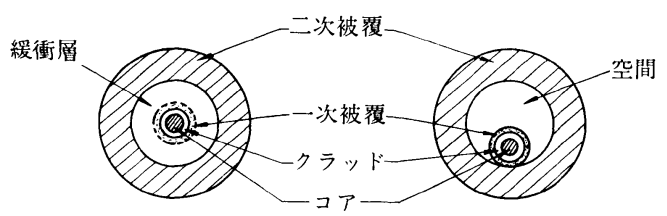

a. 三層構造心線

b. ルース構造心線

図 1 代表的な光ファイパの構造

*住友電気工業秼横浜研究部（干244 横浜市戸塚区田 谷町 1)

Sumitomo Electric Industries Ltd., Laboratory Yokohama (1, Taya-machi, Totsuka-ku, Yokohama-shi, 244)
Gotaro TANAKA* and Kazunori MATSUI*

振動に基づく赤外吸収，㧍よび屈折率・濃度ゆらぎに基 つくくレイレイ散乱損であり，本質的にはこれらから決ま る損失の空が選択できる。そしてファイバの合成過程で 入りこむ二次的要因の不純物による吸収損, ファイバ構 造の不完全性からくる散乱損を十分に除去する必要があ る。表 2 に代表的な不純物による損失レベルを示す。フ アイバの伝送損失は技術が向上すれば究極的には固有損 失レベルまで下げることができる。また，この值は構成 材料の選択によりほぼ決定されることになる。

(2)の伝送歪を少くするためには，コア部とクラッド部 とに精密な屈折率差を構成しまた，コア内に所定の屈 折率分布を形成する必要がある。

(3)については, ファイバの破壊は主として材料の本質 強度（原子間結合力の強さ），および表面欠宿に依存す る。そこで本質強度が強い材料を選び，また表面欠陥の 発生を極力なくし，保護することが重要となる。

ファイバの構成材料としては, 無機材料（ガラス, 結 晶), 有機材料, 複合材料 (有機・無機) があり，それ ぞれ長所・欠点を有するものが得られるが, 現在, 最も 特性がよく, 実用上からも欠点の少いものが, 気相合成 による石英系ガラスファイバである。この石英系ガラス ファイバの低損失波長域は, $1.3 \mu \mathrm{m}$ 拈よび $1.5 \mu \mathrm{m}$ 近傍 の近赤外領域であり,この波長域が長距離・大容量通信 に用いられる。図2に，ほぼ固有損失レベルまで達して いるとみられる石英系光ファイバの伝送損失の実現值を 示す。

石英系光ファイバの屈折率の調整には, $\mathrm{GeO}_{2}, \mathrm{P}_{2} \mathrm{O}_{5}$, $\mathrm{Al}_{2} \mathrm{O}_{3}, \mathrm{~B}_{2} \mathrm{O}_{3}$, F などが使用される。図 3 にこれら添加剤 濃度と屈折率值の関係を示す。現在, $\mathrm{GeO}_{2}$ が最も広く 用いられている。これは，その添加によって結晶の生成 や光吸収の発生がなく，また高純度で蒸気圧の比較的高 い原料 $\left(\mathrm{GeCl}_{4}\right)$ があり，気相で合成し易いなどの長所 による。ただし $\mathrm{Ge}$ は，資源的には恵まれた材料でなく， また産出国がザイール1国に偏るなどの点で, 将来の大 量生産時（例总ば 100 万 $\mathrm{km} /$ 年オーダ）には問題となる 可能性がある2。また，高屈折率差（二高 NA）ファイ バの作成用としては，多量添加が必要で，この結果石英 
表 1 光ファイバの伝送損失要因 損失 $(\lambda)=A(\lambda)+B\left(\frac{1}{\lambda^{4}}\right)+C$

\begin{tabular}{|c|c|c|c|}
\hline \multirow{2}{*}{$\begin{array}{l}\text { 吸 } \\
\text { 岗 } \\
\text { 損 } \\
\text { 作 }\end{array}$} & 固有吸収 & 紫外吸收 - 赤外吸收 & \multirow{2}{*}{$A(\lambda)$} \\
\hline & 不純物吸収 & 還移金属· $\mathrm{OH}$ 基 & \\
\hline \multirow{2}{*}{$\begin{array}{l}\text { 嚾 } \\
\text { 乱 } \\
\text { 損 } \\
\text { 作 }\end{array}$} & 固有散乱 & レイレイ散乱 & $\mathrm{B}\left(\frac{1}{\lambda^{4}}\right)$ \\
\hline & 構造不完全性 & $\begin{array}{l}\text { アワ・コア界面不整 } \\
\text { マイクロベンディング }\end{array}$ & $\mathrm{C}$ \\
\hline
\end{tabular}

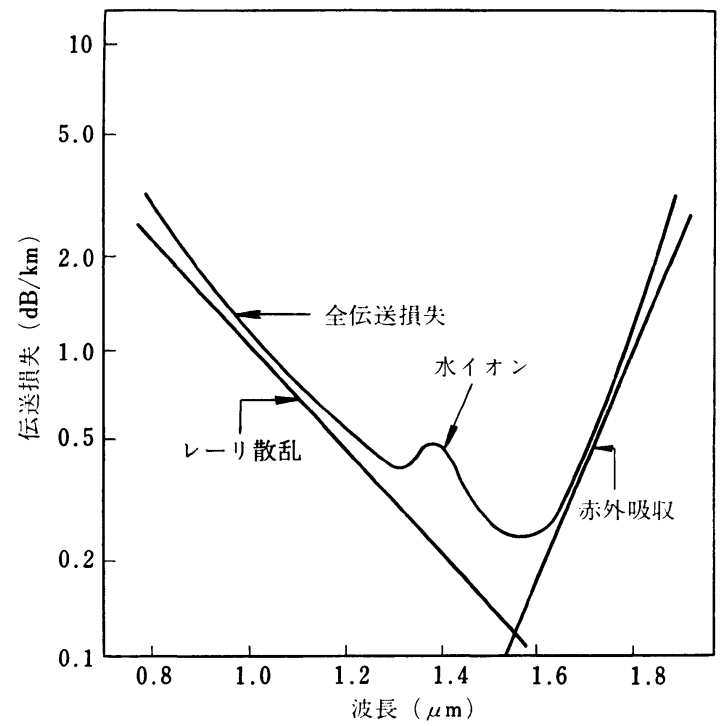

図 2 石英系光ファイハの伝送損失 (残留 $\mathrm{OH}$ は数 $\mathrm{ppb}$, 遷移金属は $\mathrm{ppb}$ ) オォータ以下, 製法はVAD 法による)

ガラスとの物性值（特に膨張係数）のズレが大きくなり ファイバの形成が難しくなること，コストが高くつくこ との点で好ましくない。

$\mathrm{P}_{2} \mathrm{O}_{5}$ を添加すると, 石英がラスの溶融温度が大きく 低下するため，ガラス合成時の長所となる。ただし，近 頃 $\mathrm{P}_{2} \mathrm{O}_{5}$ 添加型ファイバは, 水素めるいは水分の拡散侵入 による伝送損失の経時増加を受け易いことが判明し ${ }^{3)}$, この点では好ましくない。

$\mathrm{TiO}_{2}$ は, ファイバ開発の初期段階でとりあげられた もので, 屈折率を上げる効果が大きく, また, 膨張係 数, 蒸気圧などの物性値が石英ガラスの值に近く, ファ

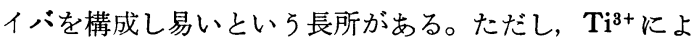
る光吸収がありこれをなくしてゆくことは難しいが特 殊な高 NAファイバには適している。

$\mathrm{Al}_{2} \mathrm{O}_{3}$ は, 豊富な材料であり, 安価な添加剂といえる が，結晶化を生じ易く，添加プロセスも難しい。

以上は，屈折率を上げる材料であるが，下げる添加剤
表 2 不純物による 吸収損失 ${ }^{1)}$

\begin{tabular}{lcl}
\hline \hline 元素 & $0.85 \mu \mathrm{m} \lambda$ & $1.3 \mu \mathrm{m} \lambda$ \\
\hline $\mathrm{Fe}$ & 0.2 & 0.2 \\
$\mathrm{Ni}$ & 0.1 & 0.2 \\
$\mathrm{Cu}$ & 0.1 & 0.2 \\
$\mathrm{Cr}$ & 1.4 & 0.7 \\
$\mathrm{OH}$ & & 0.001 \\
\hline \hline
\end{tabular}

$(\mathrm{dB} / \mathrm{km} / \mathrm{ppb})$
表 3 可視城に近い赤外 吸収ピーク位㯰

\begin{tabular}{lc}
\hline \hline 材料 & 赤外吸収ピーク \\
\hline $\mathrm{SiO}_{2}$ & $9.1 \mu \mathrm{m}$ \\
$\mathrm{GeO}_{2}$ & $11.4 \mu \mathrm{m}$ \\
$\mathrm{P}_{2} \mathrm{O}_{5}$ & $7.8 \mu \mathrm{m}$ \\
$\mathrm{B}_{2} \mathrm{O}_{3}$ & $7.4 \mu \mathrm{m}$ \\
$\mathrm{SiF}$ & $13.8 \mu \mathrm{m}$ \\
\hline \hline
\end{tabular}

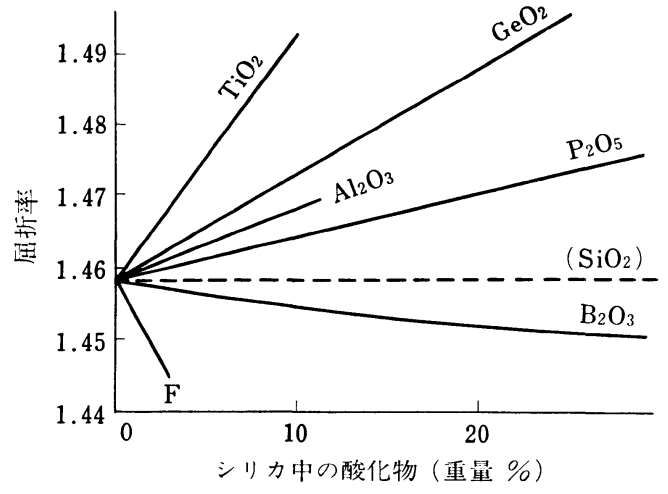

図 3 添加剤濃度と屈折率の関係

としては, $\mathrm{B}_{2} \mathrm{O}_{3}$ および $\mathrm{F}$ がある。 $\mathrm{B}$ の添加は, 赤外吸 収をより短波長化するため, $1.3 \sim 1.5 \mu \mathrm{m}$ 波長域での使 用には，その吸収の影響が出てくる。表 3 に赤外吸収ピ 一クの波長を示す。一方, $\mathrm{B}$ の添加により, 膨張係数を 大きくできるため, 残留応力を利用する定偏波ファイバ の製造用として適している。

最近, 石英ガラスの屈折率を下げる添加剂として, フ ッ素が注目され4，これをクラッドに入れたファイバが 作られている。フッ素添加の㸚らいは，(1)伝送損失（特 にレイレイ散乱損がより小さくなる) および耐放射線特 性に優れた 純 $\mathrm{SiO}_{2}$ ガラスをコアとするファイバを得る ことができること（最近 $0.16 \mathrm{~dB} / \mathrm{km}$ といら損失值が, このタイプのファイバで得られた ${ }^{5)}$ ), (2)ガラスの加工温 度が下げられること（3)コアとクラッドの屈折率差をよ り大きくできること（例えば， NA=0.4という多成分 系ファイバに迫る高 $\mathrm{NA}$ ファイバの実用化 $\left.{ }^{6)}\right)$, の 3 点で ある。

以上あげた添加剤の 5 ち, 蒸気圧の高いもの $\left(\mathrm{P}_{2} \mathrm{O}_{5}\right.$, $\mathrm{B}_{2} \mathrm{O}_{3}, \mathrm{GeO}_{2}$ ) は, 気相合成反応において収率が低くなり, 直接溶融状態では殆んど添加することができない。これ を解決したプロセスがスートプロセス（より低温下でガ ラス微粒子の集合体＝半焼結体を合成し，これをその後 に焼結して透明ガラス化する）である7。 


\section{3. 石英系光ファイパの製造方法}

石英系光ファイバをつくるには，あらかじめコア， ク ラッドを構成させた棒状ガラス母材（プリフォームと称 する）を合成し，これを約 $2000^{\circ} \mathrm{C}$ の電気炉で溶融線引 してファイバとする。表 4 亿石英系ガラスファイバの製 造法とその特徵を示す。この中で実用化しているものが 気相法によるプロセスである。この中で長尺・高品質 な光ファイバの製法として, 現在最も代表的なものが MCVD 法, VAD 法，OVD法である。

\section{3-1 MCVD 法 (Modified Chemical Vapor Deposition $)^{8)}$}

1974年に米国のベル研究所(現在の A T Tテクノロジ) の MacChesney らが，本方法により $2 \mathrm{~dB} / \mathrm{km}$ とい5固 有損失レベルに近い低損失なファイバを発表し9)，一躍

表 4 石英系ガラスファイバの製造法

\begin{tabular}{|c|c|c|c|c|c|}
\hline \multicolumn{3}{|c|}{ 反応 積層方向 } & 内方 向 & 外方 向 & 軸方 [问 \\
\hline \multirow[b]{2}{*}{ 気 } & 熱化 & $\begin{array}{l}\mathrm{SiCl}_{4}+\mathrm{O}_{2} \\
\rightarrow \mathrm{SiO}_{2}+2 \mathrm{Cl}_{2}\end{array}$ & M-CVD法 & & \\
\hline & \multirow{2}{*}{$\begin{array}{l}\text { 火 } \\
\text { 炎 } \\
\text { 法 }\end{array}$} & $\begin{array}{l}\text { 火炎加水分解 } \\
\mathrm{SiCl}_{4}+2 \mathrm{H}_{2}+\mathrm{O}_{2} \\
\rightarrow \mathrm{SiO}_{2}+4 \mathrm{HCl}\end{array}$ & & OVD法 & VAD法 \\
\hline 相 & & $\begin{array}{l}\text { 火炎酸化 } \\
\mathrm{SiH}_{4}+2 \mathrm{O}_{2} \\
\rightarrow \mathrm{SiO}_{2}+2 \mathrm{H}_{2} \mathrm{O}\end{array}$ & & & $\begin{array}{l}\mathrm{SiH}_{4} \text { 法 } \\
\left(\mathrm{SiO}_{2} \text { のみ }\right)\end{array}$ \\
\hline \multirow[t]{2}{*}{ 法 } & \multirow{2}{*}{$\begin{array}{l}70 \\
\overline{7} \\
\text { Z゙ } \\
\text { 资 } \\
\text { 炎 } \\
\text { 法 }\end{array}$} & $\begin{array}{l}\text { 低温プラズマ } \\
\mathrm{SiCl}_{4}+\mathrm{O}_{2} \\
\rightarrow \mathrm{SiO}_{2}+2 \mathrm{Cl}_{2}\end{array}$ & P-CVD法 & & \\
\hline & & $\begin{array}{l}\text { 高温プラズマ } \\
\mathrm{SiCl}_{4}+\mathrm{O}_{2} \\
\rightarrow \mathrm{SiO}_{2}+2 \mathrm{Cl}_{2}\end{array}$ & P-MCVD法 & P-OVD法 & \\
\hline & 液 & 法 & \multicolumn{3}{|c|}{ ゾルゲル法 } \\
\hline & 固 & 相 & 分 & 法 & \\
\hline
\end{tabular}

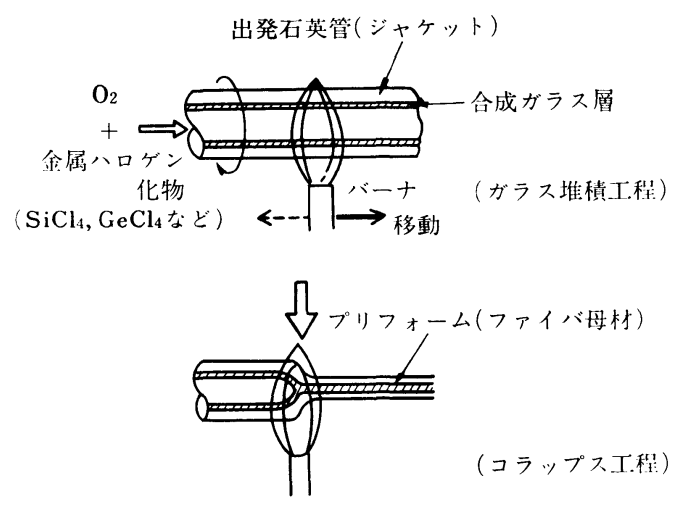

図 4 MCVD 法概要図
有名となった。ただし，このプロセスの原型としては， コーニング社の一層内付法 ${ }^{10)}$, 二層内付法 ${ }^{11)}$, ISE 社の 内付コラップス法 ${ }^{12}$, 住友電工の内付濃度分布形成法 ${ }^{132}$ などがある。この MCVD 法では，比較的容易に低損失 ファイバが得られるので, 各所でフォローされ，全世界 にこのプロセスが広まった。

図 4 にプロセスの概要図を示す。ガラス旋盤に取りつ けられた石英ガラス管内に，酸素と $\mathrm{SiCl}_{4}$ などのガラス 形成用塩化物ガスを流し，移動加熱源によって局所加熱 することにより，酸化物ガラス微粒子(スートと称する) を石英ガラス管内に発生させ，このスートを管内壁に堆 積させる。この堆積したスートは移動してくる加熱源に より連続的に溶融ガラス化され，管内壁にガラス膜が形 成される。このガラス膜堆積工程を数 10〜数100 回絽返 した後に，原料ガスの供給を停止し，より高温で加熱し て石英管を収縮させ管を充実化する。この工程をコラッ プス工程 ${ }^{12)}$ と称し，これにより棒状ガラス母材（プリフ オーム)を得る。屈折率分布は，合成するガラス膜の各 蔡毎に原料ガスの流量比を変えることにより形成する。

MCVD 法を洗練させた技術のいくつかを表 5 に示す。

\section{3-2 VAD 法 (Vapor Axial Deposition) ${ }^{19), 20)}$}

VAD 法は電電公社等が 開発を進めてきた純国産技術 で，母材を連続的に軸方向に合成できる特徵がある。図 5 に装置の概要，図 6 にプロセスの概要を示す。

原料供給系は MCVD 法とほぼ同様である。酸水素炎 中に原料ガスを供給し，火炎中での加水分解反応により

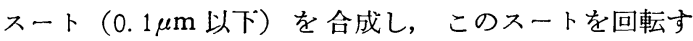

表 5 MCVD 法に抢ける改良技術

\begin{tabular}{|c|c|c|c|}
\hline 改 良 技 術 & 极 & 5 & w \\
\hline 管径制御 $(\text { 内圧制御 })^{14)}$ & \multicolumn{3}{|c|}{$\begin{array}{l}\text { ・ガラス堆積過程で生じる出発石 } \\
\text { 英管の湾形を压制御を } \\
\text { 行っで防止する。 } \\
\text { ・堆積ガラス厚を厚く形成できる。 }\end{array}$} \\
\hline $\begin{array}{l}\text { 原料添加コラプス法 } \\
\text { エッヂ } \\
\text { (1) }\end{array}$ & \multicolumn{3}{|c|}{$\begin{array}{l}\text { ・コラプス過程で生じる添加剤の } \\
\text { 揮散による変動を抑制す } \\
\text { る。 }\end{array}$} \\
\hline 管壁冷却 ${ }^{16)}$ & \multicolumn{3}{|c|}{$\begin{array}{l}\text { ・サーモフォレシス効果を利用し } \\
\text { てガラスの堆積効率を向上させ } \\
\text { る。 }\end{array}$} \\
\hline 塩素導入コラプス法 ${ }^{17)}$ & \multicolumn{3}{|c|}{$\begin{array}{l}\text { ・ OH污染の生じ易いコラプス時 } \\
\text { に, Cl } \mathrm{Cl}_{2} \text { ガを導入して低 } \\
\text { 化を図る。 }\end{array}$} \\
\hline He 添加堆積法 ${ }^{18)}$ & \multicolumn{3}{|c|}{$\begin{array}{l}\text { ・原料ガスに He を唀加すること } \\
\text { で透明ガラス华を容にしで } \\
\text { ガラスの合成速度を向上させる。 }\end{array}$} \\
\hline
\end{tabular}


る出発棒先端に軸方向に半焼結状態で堆積させてゆく。 得られたスート体を電気炉に挿入し塩素導入下で脱水 し，透明ガラス化する。この脱水処理工程により，残留 $\mathrm{OH}$ 量の極めて少ないファイバが得られる。屈折率分布 は, (1)火炎内でのドーハントの拡散および, (2)堆積表面 温度分布により決まり,これらを高度に調節する必要が ある。 $\mathrm{GeO}_{2}$ 添加の場合には，特に(2) が重要である。原 料の堆積収率は MCVD 法に比べて高い。また, MCVD 法では低 $\mathrm{OH}$ 化を図るために原料の高純度化，配管系の 吸湿対策, コラップス時の低 $\mathrm{OH}$ 化手法等, 特殊な工夫 が必要であるが, VAD 法ではスート体自体が多量に $\mathrm{OH}$

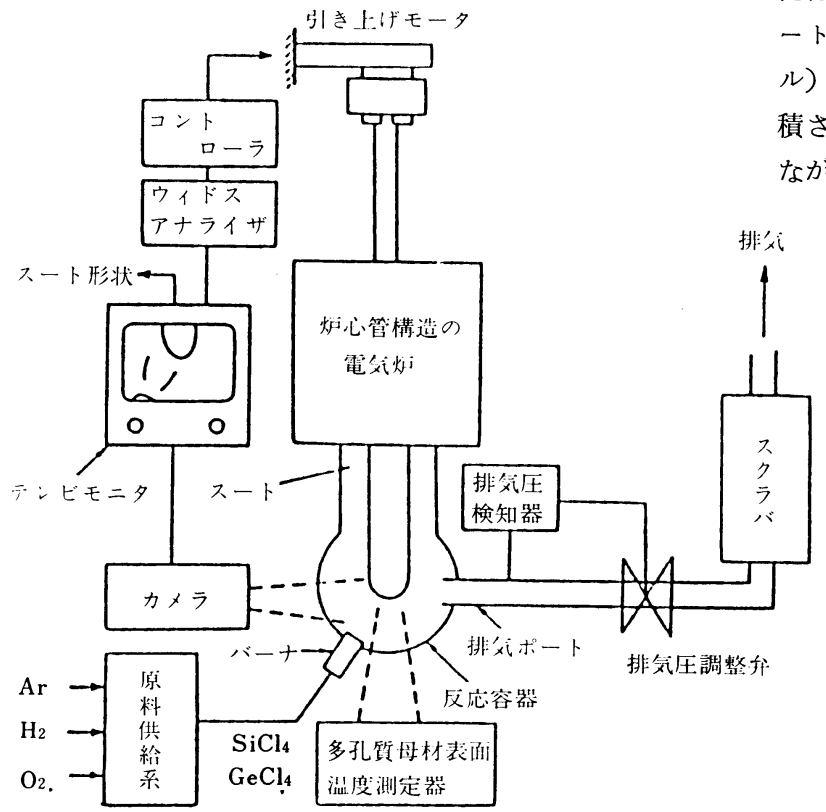

図 5 VAD 装置の概要（連続合成法の場合）

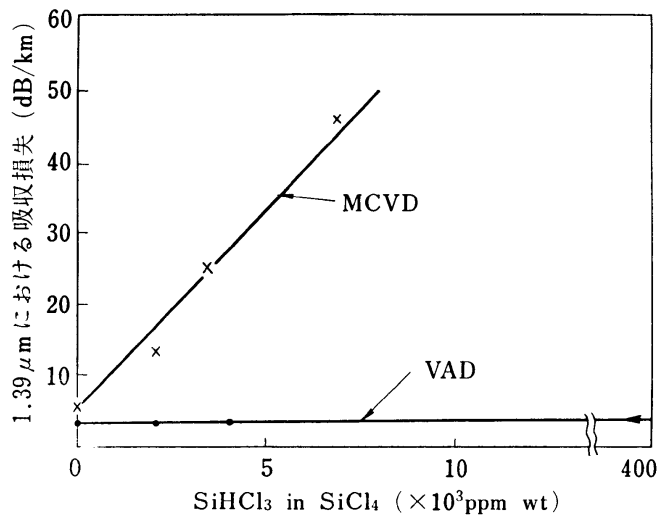

図 $7^{21} \mathrm{SiHCl}_{3}$ 含有原料による $1.39 \mu \mathrm{mOH}$ 吸収損失 の関係 (MCVD 法では $\mathrm{SiHCl}_{3}$ 含有量ととも に吸収損失が増加するが, VAD 法では増加 しない)
を含有するものの, 脱水処理工程により, より容易に低 $\mathrm{OH}$ Hファイバを実現することができる。また，原料自 体を特に高純度にする必要がない(図 7 参照) ${ }^{21}$ 。

また，大型・長尺の合成ガラスが得られるので，合成 クラッド層を厚く形成しなければならないシングルモー ドファイバの製造には特に有利となる。

\section{3-3 OVD 法 (Outside Vapor Deposition) 22),23)}

コーニング社によって開発された方法であり, 図 8 に その概要図を示す。この方法は, スートプロセスを光フ アイバの製造に適用した最初のプロセスである。

$\mathrm{VAD}$ 法と同じくバーナに原料と酸素および水素（ま たは天然ガス）を供給し，火炎加水分解を生じさせてス ートを合成し，このスートを回転する出発棒（マンドレ ル）の外周部に半焼結状態で堆積させてゆく。所定量堆 積させた後，マンドレルを引き抜き，電気炉中で脱水し ながら透明ガラス化する。屈折率分布は, MCVD 法と

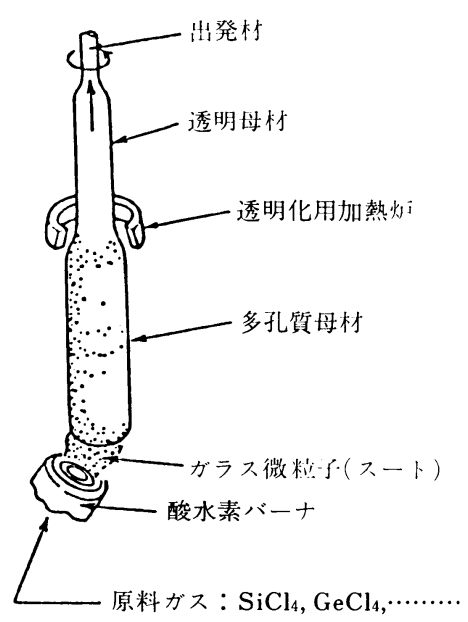

図 6 VAD 法によるガラス合成 （連続製造の場合）
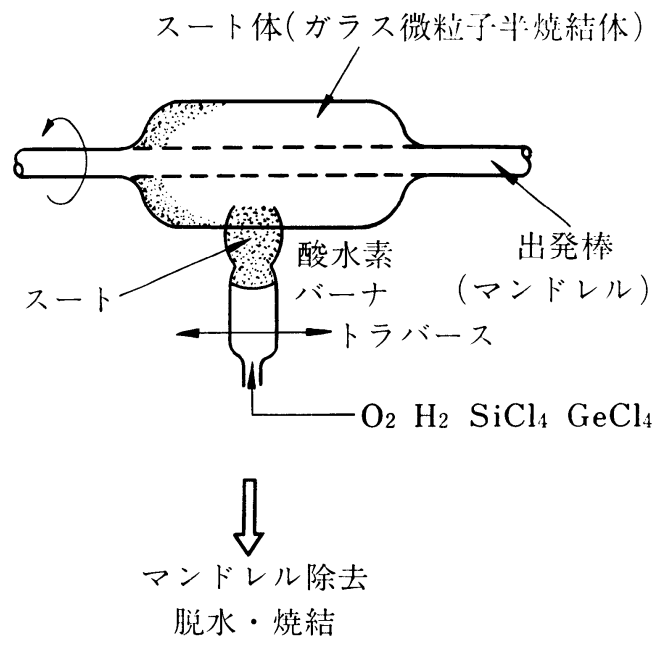

図 8 OVD 法 
同じく，堆積層毎に原料組成比を変えることで形成させ る。生産性はVAD 法と同等であるが，コラップス工程 が必要であり,また，連続製造はできない。

\section{3-4 Plasma 法 (P-CVD ${ }^{24)}$, P-MCVD ${ }^{25)}$, P-OVD ${ }^{26)}$ )}

前記した方法はいずれも, 反応の加熱源として酸水素 炎を用いているが，この代りに，低温（=減圧）プラズ マ，あるいは高温プラズマを利用する方法がある。

表 6 亿，それらの方法の特徵を示す。低温プラズマを 用いる P-CVD 法は，気相と管内壁とでへテロジニアス な反応を低温下で生じせしめている点で他のスートプロ セスと大きく異なる。

\section{3-5 線引}

プリフォームを光ファイバにする工程を線引という。 図 9 に線引装置の概略を示す ${ }^{27)}$ 。線引機の基本構成は主 として，(a)プリフォーム送り部，(b)線引炉，(c)コーティ ング部，(d)ファイバ巻取り部，(e)線径制御部である。光 ファイバの線引装置は, 光ファイバに要求される高強 度, 低損失, 高精度の線径均一性等を実現する様技術開 発されたものである。表 7 に光ファイバ特性と関連する 線引の要素技術，その開発例を示す。本稿では，(b!，(c) を中心として述べる。

線引炉は，光ファイバの強度特性を決定する主要因の 一つで, $2000^{\circ} \mathrm{C}$ 以上の高温での温度安定性, 炉の清浄性 が要求される。線引炉の熱源としては，カーボン抵抗27) 炉，ジルコニア誘導炬 ${ }^{28)}, \mathrm{CO}_{2} レ$ レ゙ー29), 酸水素炎 ${ }^{30)}$ 等が検討されている。 $\mathrm{CO}_{2}$ レーザーは清浄性の点では優 れているが，温度安定性，取扱い性等に問題があり，酸 水素炎は炎の変動のため線径制御が困難となるなどの欠 点があり，両者とも製造設備には適していない。

高純度カーボンを発熱体とした抵抗炉は，線引温度の 安定性に優れ，その取扱い性も容易であるので製造設備 に使用される場合が多い。炉内の清浄性を保つため, 炉 心管をつけ，炉内で発生するダストを強制的に排出する 工夫もなされている ${ }^{31}$ 。線径制御の観点からは，線引炉 の構造,パージガス流量の検討も必要である。

ジルコニアの誘導炉 む製造設備でよく使用されてい る。カーボン炉と異なりパージガスは必要ないが炉内の 清浄性を保つためにクリンエアを吹流す場合もある ${ }^{32) 。 ~}$

表 6 Plasma 法による光ファイバの製造

\begin{tabular}{|c|c|c|}
\hline 製 法 & 開発機関 & 徴 \\
\hline $\mathrm{P}-\mathrm{CVD}^{24)}$ & Philips 社 & $\begin{array}{l}\text { ・出発石英管内を } 1 \sim 100 \mathrm{mmHg} \text { に减圧し，プラズマを } \\
\text { 管内に発生させて管内壁にガラス膜を堆積させる。 } \\
\text { ・ 反応収率が } 80 \sim 100 \% \text { と高い。堆積速度は } 0.5 \mathrm{~g} / \text { 分程 } \\
\text { 度。F多く添加できる }([\mathrm{F}] \fallingdotseq 8 \mathrm{wt} \%) 。 \\
\end{array}$ \\
\hline P-MCVD ${ }^{20)}$ & BTL & $\begin{array}{l}\text { ・出発石英管内に熱プラズマを発生させて, 管内壁にガ } \\
\text { ラス膜を形成させる。 } \\
\text { ・堆積速度を数 } \mathrm{g} / \text { 分と大きくできる。 }\end{array}$ \\
\hline $\mathrm{P}-\mathrm{OVD}^{26)}$ & Heraeus & $\begin{array}{l}\text { ・出発コアガラスの外周部に, プラズマトーチによる火 } \\
\text { 炎反応を用いたスートを堆積・溶融させる。 } \\
\text { ・Fクラッド層を形成するのに適している。 }\end{array}$ \\
\hline
\end{tabular}

表 7 光ファイバ特性と要素技術

ファイバ
特

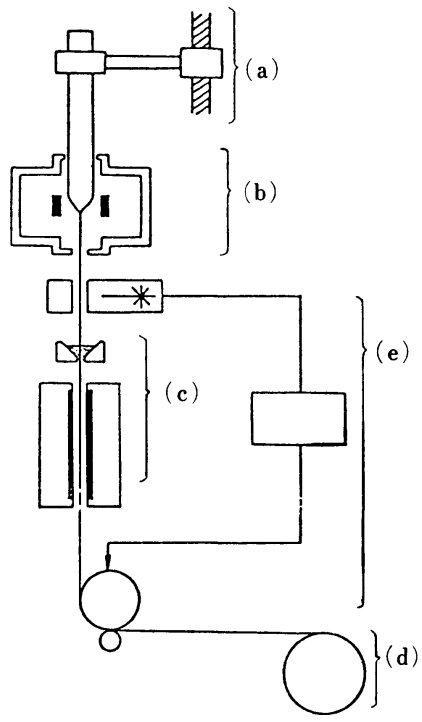

(a) プリフォーム送り部

(b) 線引恼

(c) コーティング部

(d) ファイバ巻取部

( ) 線径制御部

図 9 石英系ファイバの 線引装㯰 ${ }^{27)}$ 
光ファイバのコーティング方法は, そのコーティング 材料と密接な関係があり, 光ファイバの強度特性, 伝送 特性に重大な影響を与える。熱硬化型シリコーン樹脂, 紫外線硬化型ウレタンアクリレイト樹脂, エポキシアク リレイト樹脂等の高分子が通常光ファイバのコーティン グに用いられるが，開放型のダイスでュートするのが主 である ${ }^{33)}$ 。高速化を福ら5場合コーティング材料のすべ りが生じるので, 密閉構造の加圧型ダイス等の開発が必 要となる ${ }^{34)}$ 。また約 $1 \mu \mathrm{m}$ の紫外線硬化樹脂の薄膜をス プレーコートした後, シリコーン樹脂をダイスでコート する技術も開発されている35)。この光ファイバの特徽 は, シリコーンの皮むき性が良く(ファイバ同士の接続 時に被覆を除去し易い)，接続強度が大きいとい5点で ある。コーティングの偏肉は, 強度, 伝送損失に悪影響 を与えるので, 偏肉を検知して防止する工夫も行われて いる ${ }^{36)}$ 。

一般にコーティング材料は先に述べたものがしばしば 使用されるが，コーティングの不均一性等に由来するマ イクロベンド損失（ファイハの微小曲りに基づく伝送損 失）を防止する効果の点でシリコーン樹脂は極めて優れ ている ${ }^{37)}$ 。通常シリコーン樹脂だけではもろいため, ナ イロンを押出被覆してヶーブルに使用される。標準的構 造は, 光ファイバ $125 \mu \mathrm{m}^{\phi}$, シリコーン樹脂 $400 \mu \mathrm{m}^{\phi}$, ナイロン $900 \mu \mathrm{m} \phi$ である。

光ファイバには, 一定の応力を加えておくと, 傷が生 長して破断に至る静疲労とい5現象がある ${ }^{38)}$ 。通常は, 使用時の寿命保証を考虑して, あらかじめ $0.5 \%$ 程度の 伸び丕を光ファイバに加え，生き残ったものを使用す る。海底ケーブルのように，特殊な条件下で使用される ものについては， $2 \%$ 程度の伸び歪を要求される場合も ある ${ }^{39)}$ 。疲労現象を抑制する手段として, 光ファイバに シリコンナイトライド(0), シリコンオキシナイトライ

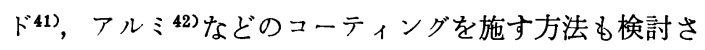
れているが, 初期強度, 伝送特性等の点で問題があり, まだ実用化には至っていない。

\section{4. その他の光ファイパの製造方法}

\section{4-1 多成分系光ファイバ}

多成分系による光ファイバの開発は, 石英系ガラスよ りも早く着手され，1970年頃には $100 \mathrm{~dB} / \mathrm{km}$ 程度の光〉 アイバが開発されていた。製法としては，2重るつぼ法 が代表的なるのである。ガラスの原料は, 蒸留・イオン 交換・溶媒抽出法などの方法で精製した後，石英または 白金などのるつぼで溶融し，るつぼの底からガラスを引 き出し, 線引する。一般に, 各種固体原料中に含まれる 不純物あるいはるつぼからの污染を完全に防ぐことは難 しく, 石英系ファイバ程には低損失化が果せていない。
ただし，加工温度が低く，安価に製造できること，組成

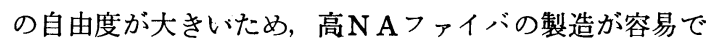
あること、などの利点がある。

\section{4-2 プラスチックファイバ}

加工や取扱いが容易であり，低価格なファイバであ る。ポリマ中の $\mathrm{C}-\mathrm{H}, \mathrm{C}=\mathrm{O}$ などの振動吸収や密度ゆら ぎによるレイレイ散乱損失は近赤外域で大きな損失要因 でありここれらのため低損失化はかなり難しい。実用化 している例は，PMMAをコアに，フッ化ビニリデン系 ポリマをクラッドとしたもの，ポリスチレンをコアに， ポリメタクル酸メチルをクラッドとしたものなどがあ る。製法としては, 2 重るつぼ法, 重合紡糸法がある。 低損失化の検討としては, ポリマ中の水素を重水素で置 換し， C-H 結合の振動吸収を長波長側に移すことで, $20 \mathrm{~dB} / \mathrm{km}$ (at $0.66 \mu \mathrm{m}$ 波長) という低損失なファイバが 得られている。

用途としては，伝送損失の点から，短距離伝送用ある いは, 胃カメラなどの短尺イメージファイバや, 自動車 灯火モニタ，ディスプレイ用などがある。

\section{4-3 プラスチッククラッドファイバ}

無機ガラスをコアに, 有機材料をクラッドとするファ イバで,コアに純粋石英ガラス，クラッドにシリコン樹 脂を用いたものが実用化されている。製法としては，高 純度石英ガラス棒を電気炉で溶融線引し，ダイスにより シリコン樹脂を被覆している。低損失のステップインデ クスファイバ（コア・クラッドの屈折率分布が一定值な ファイバ）が容易に製造できるが，欠点としては，接続 が難しいこと，また耐候性の点で信頼性に劣ることであ る。

\section{4-4 赤外ファイバ}

光伝送損失の大きな要因の 1 つであるレイレイ散乱損 失は，長波長程小さくなるため，格子振動に基づく赤外 吸収がより長波長側にシフトした物質では, 石英系ガラ スファイバよりもさらに低損失なファイバの得られる可 能性がある。また，熱情報の伝送（測温）あるいは炭酸 ガスレーザ (10.6 $6 \mu \mathrm{m}$ 波長) のエネルギ伝送を可能とす る。これらファイバの材料としては, 振動吸収の面か ら，原子量が大きくゆるい結合をした材料が好ましく， 八ロゲン化物・カルコダナイド化合物などの非酸化物が 有利である。一方, これらの物質は本質的に結晶化し易 く，また強度，耐候性の面で弱いため，信頼性を具えた 長尺ファイバを構成するには現在のところ十分でない。

図10に各種材料の理論検討例を示す43)。表 8 に実際に 検討された材料例を示す。表 9 に $\mathrm{CO}_{2}$ レーザ伝送用フ アイバの特性例を示す。 $\mathrm{AgCl}-\mathrm{AgBr}$ 系， TIBr-TII 系な どは数 $\mathrm{m}$ 長のレーザメス等のエネルギ伝送用として実用 化し始めている。製造法としては, ガラスは母材線引 


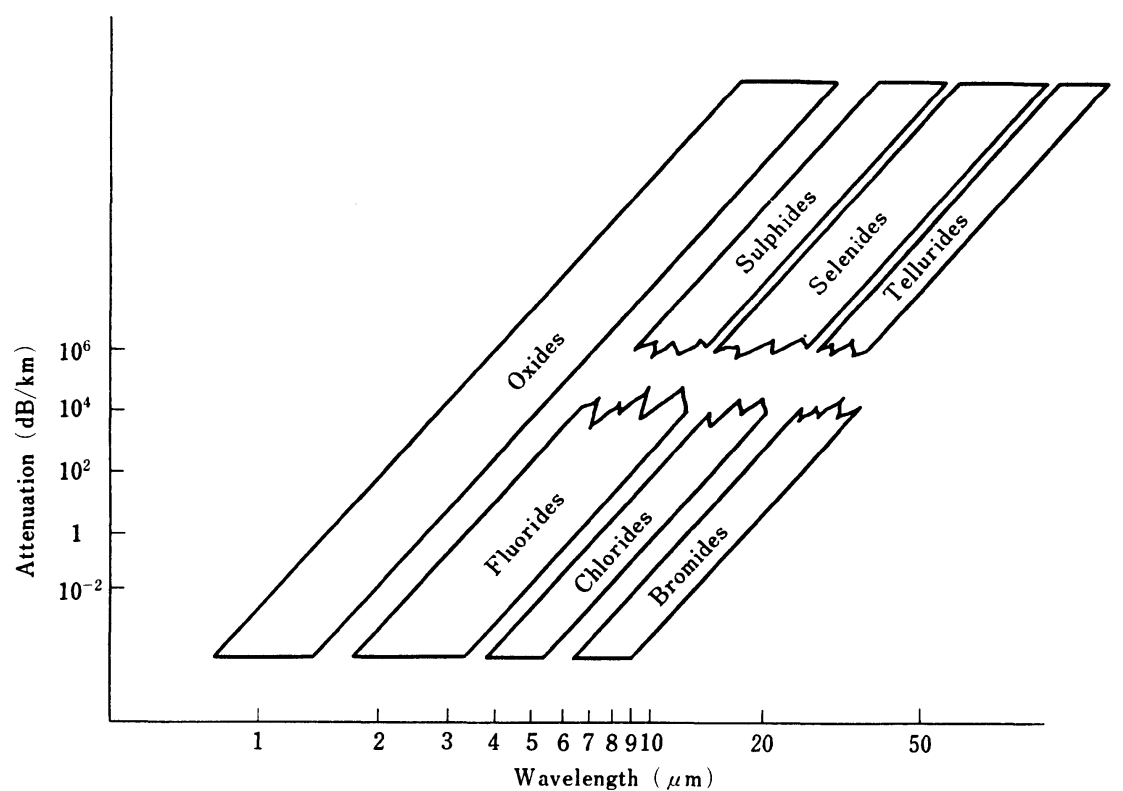

図10各種材料の赤外域吸収レベル43)（理論值：J.R. Gannon）

表 8 既発表の主な赤外ファイバ一覧

\begin{tabular}{|c|c|c|}
\hline 類 & 形態(対象波長) & 組 \\
\hline \multirow{3}{*}{$\begin{array}{l}\text { 金口焦属 } \\
\text { 化 }\end{array}$} & 単 $(10.6 \mu \mathrm{m})^{\text {晶 }}$ & $\begin{array}{l}\mathrm{AgBr}, \mathrm{AgCl}, \mathrm{KCl}, \mathrm{KBr}, \\
\mathrm{KRS}-5(\mathrm{TlBr}-\mathrm{TlI}) \text { など }\end{array}$ \\
\hline & 多 $(10.6 \mu \mathrm{m})^{\text {晶 }}$ & $\begin{array}{l}\mathrm{KRS}-5, \mathrm{TlBr}, \mathrm{CsI}, \mathrm{LiF}, \\
\mathrm{KCl}, \mathrm{KBr}, \mathrm{KI}, \mathrm{NaCl}, \\
\mathrm{NaF}, \mathrm{AgCl}-\mathrm{AgBr}\end{array}$ \\
\hline & ${ }^{カ ゙}(2 \sim 4 \mu \mathrm{m})^{\text {ス }}$ & $\begin{array}{l}\mathrm{BeF}_{2}, \mathrm{LaF}_{2}-\mathrm{BaF}_{2}-\mathrm{ZrF}_{2}, \\
\mathrm{BaF}_{2}-\mathrm{GdF}_{3}-\mathrm{ZrF}_{4}-\mathrm{AlF}_{3}, \\
\mathrm{ZnCl}_{2}\end{array}$ \\
\hline 酸 化 物 & ${ }^{\text {ガ }} \stackrel{\text { ラ }}{\left.2^{2} \mu \mathrm{m}\right)^{\text {ス }}}$ & $\begin{array}{l}\mathrm{TeO}_{2}-\mathrm{ZnO}_{2}-\mathrm{BaO}, \mathrm{GeO}_{2}- \\
\mathrm{Sb}_{2} \mathrm{O}_{3}, \mathrm{CaO}-\mathrm{Al}_{2} \mathrm{O}_{3}\end{array}$ \\
\hline $\begin{array}{l}\text { カルコゲン } \\
\text { 化 物 }\end{array}$ & ${ }^{\text {カ }} \underset{(2 \sim 6 \mu \mathrm{m})^{\text {ス }}}{ }$ & $\begin{array}{l}\mathrm{Ge}-\mathrm{P}-\mathrm{S}, \mathrm{Ge}-\mathrm{Se}-\mathrm{As}, \\
\mathrm{La}-\mathrm{Ga}-\mathrm{Ge}-\mathrm{Se}\end{array}$ \\
\hline
\end{tabular}

法, 2 重るつぼ法があり, 単結晶は引下法, 多結晶は押 出法が用いられる。

\section{4-5 定偏波ファイバ}

偏波面を保存できるようにしたファイバのことで，(1) コアあるいはクラッドをだ円にし，残留応力分布をファ イバに加える構造としたもの（図11- I，II，III)，(2)残留 応力発生部を孤立対称的に生成させたもの（図11-IV)が ある。製法としては，非円対称的にガラスの気相堆積を 行らもの, クラッド部を非円とし, 線引時に外径が真円 状となることを利用したもの、コア近傍にその長手方向 にミゾを掘りここを応力発生層もしくは応力発生材料 を挿入溶着するものなどがある。ガラス材料としては,
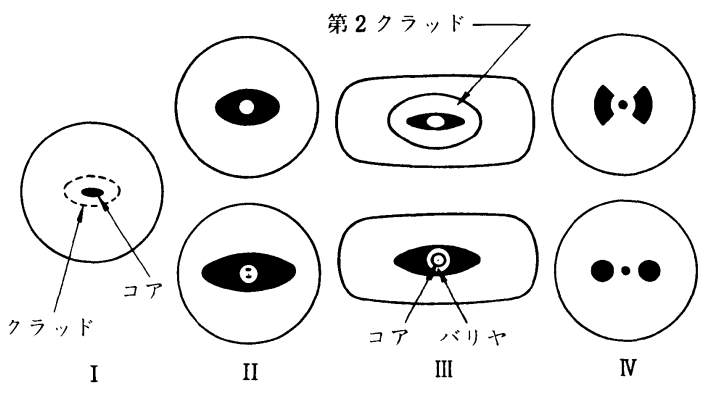

図11定偏波ファイバの構造(例49)

石英系ガラス $+\mathrm{B}_{2} \mathrm{O}_{3}$ 添

表 $9 \mathrm{CO}_{2}$ レーザ伝送用 加の組合せによるものが ファイバの特性 多い。

\section{5. 今後の課題}

光ファイバ製造分野で の今後の課題は,

(1) 電電公社 INS 計画 の端末通信網などの公衆通信加入者系統に用いうる様 な低コストファイバの大量生産技術の確立

（2）海底ヶーブルなどに用いる超低損失・超高強度ファ イバの技術開発

（3）エネルギ伝送を可能とする赤外ファイバの実用化

（4）定偏波ファイバの特性向上化 などであろう。 


\section{文献}

1) P.C. Schultz; J. Am. Ceram. Soc., 57, 309 (1974)

2）新関暢一; 電気通信研究所研究実用化報告，32, 309 (1984)

3) K. Mochizuki, Y. Namihira and H. Yamamoto; Electron. Lett., 19, 743 (1983)

4) 特公昭55-15682

5) R. C. Sencsits, P.J. Lemaire, W.A. Reed, D.S.

Shenk and K.L. Walker; in Technical Digest on Conference on Optical Fiber Communication(OFC), TUI 3, 54 (1984)

6) G. Tanaka, K. Fujiwara and K. Osaka ; OFC ' 84 , TUG 3 (1984)

7) USP-3, 644, 607, USP-4, 042, 404

8) S.R. Nagel, J.B. MacChesney and K.L. Walker; IEEE Vol. MTT-30, No. 4, 305 (1982)

9) J.B. MacChesney, et al., Proc. 10th International Congress on Glass, Vol. 6, 40 (1974)

10) USP-3, 711,262

11) USP-3, 737, 293

12）特公昭58-4323

13）特公昭59-13451

14) M. Okada, M. Kawauchi and A. Kawana;

Electron. Lett., 14, 89 (1978)

15）特公昭59-1222

16）特願昭53-58474, USP-4, 302, 230

17）特開昭55-3365

18) T. Akamatsu; Appl. Phys. Lett., 31, 174 (1977)

19）稲垣伸夫；日経エレクトロニクス 1，5，144(1981)

20) T. Izawa, S. Kobayashi, S. Sudo and F. Hanawa; IOOC '77 Technical Digest, 375 (1977)

21）千田和憲, 須田裕之, 岡崎久晃, 中原基博；昭和 55 年電子通信学会, 光 -電波部門全国大会予稿集, 357

22) USP-3, 775, 075

23) M.G. Blankenship, C.W. Deneka; IEEE. Vol. QE18, 1418 (1982)

24) D. Küppers, H. Lydtin; J. Electrochem. Soc., 125, 1298 (1978)

25) J.W. Fleming and V. Raju; Proc. 3rd IOOC, WD 2 (1981)

26) A. Muhlich, K. Rau and N. Treber; Proc. 3rd ECOC, 10 (1977)

27）中原基博, 坂口茂樹, 宮下忠; 電気通信研究所研究 実用化報告，26，2557（1977）
28) L.L. Blyler, Jr. and F.V. DiMarcello; Proceeding of The IEEE, 68, 1194 (1980)

29) R.E. Jaeger; Ceramic Bulletin, 55, 270 (1976)

30) T.T. Wang and H.M. Zupko; Fiber and Integrated Optics, 3, 73 (1980)

31) S. Sakaguchi, M. Nakahara and Y. Tajima; $J$. Non-Cryst. Solids, 64, 173 (1984)

32) F.V. DiMarcello, A.C. Hart, Jr., J.C. Williams and C.R. Kurkjian; Fiber Optics, Advances in Research and Development, Edited by B. Bendow and S.S. Mitra (Plenum Publishing Corporation, pp. 125 1979)

33）倉内憲孝, 椋梨浩明; SEN-I GAKKAISHI（織維と 工業) 39, 171 (1983)

34）千田和憲, 木村隆男, 我妻誠; 電気通信研究所研究 実用化報告，32，2675（1983）

35) K. Tsuneishi, T. Yamanishi, S. Suzuki and M. Yoshida; OFC'84, WF 8 (1984)

36) D.H. Smithgall and R.E. Frazee, Jr; OFC' 82 WCC5 (1982)

37) T. Yamanishi, K. Yoshimura, S. Suzuki, S. Seikai and N. Uchida; Electron. Lett., 16, 100 (1980)

38）木村隆男，柴田修一，坂口茂樹，首藤義人，中原基 博, 高橋志郎; 研究実用化報告, 29, 1771 (1980)

39) N. Kojima, Y. Miyajima, Y. Murakami, T. Yabuta, O. Kawata, K. Yamashita and N. Yoshizawa; IEEE J. Quantum Electron., QE-18, 733 (1982)

40) R. Hiskes; OFC'79, WF 6 (1979)

41) C.A. Schantz, E.G. Hanson and R. Hiskes; OFC'82, WCC 2 (1982)

42) D.A. Pinnow, J.A. Wysocki and G.D. Robertson, Jr. ; IECE, E61, 171 (1978)

43) J.R. Gannon; J. Non-Cryst. Solids, 42, 239 (1980)

44）池戸才, 筒井博, 渡正文, 胡桃沢利光; 第29回応物 学会関係連合講演会予稿集, $2 \mathrm{p}-\mathrm{W}-5,104$ (1982)

45）可知純夫，木村正樹，中村一則，增田满，城山魁 助; ibid., 2p-W-8, 105 (1982)

46）住友電工，日経新聞，9月29日（1982）

47）三村栄紀, 太田忠一; 第29回応物学会関係連合講演 会予稿集, $2 \mathrm{p}-\mathrm{W}-2$ (1982)

48）高橋謙一, 村上一借田稔; 第28回応物学会関係 連合講演会予稿集, 29a-k-2 (1981)

49) S.C. Rashleigh; CLEO'85, WH4, 100 (1985)

50）特公昭59-18327 